\title{
Pierrelatte - Rue des frères Montgolfier
}

\section{Christine Ronco}

\section{OpenEdition \\ Journals}

Édition électronique

URL : http://journals.openedition.org/adlfi/14822

ISSN : 2114-0502

Éditeur

Ministère de la culture

Référence électronique

Christine Ronco, «Pierrelatte - Rue des frères Montgolfier », ADLFI. Archéologie de la France -

Informations [En ligne], Rhône-Alpes, mis en ligne le 20 mai 2015, consulté le 30 avril 2019. URL

http://journals.openedition.org/adlfi/14822

Ce document a été généré automatiquement le 30 avril 2019

(c) Ministère de la Culture et de la Communication, CNRS 


\title{
Pierrelatte - Rue des frères Montgolfier
}

\author{
Christine Ronco
}

Code INSEE de la commune : 26235

Lien Atlas (MCC) :

http://atlas.patrimoines.culture.fr/atlas/trunk/index.php?

ap_theme=DOM_2.01.02\&ap_bbox $=4.647 ; 44.320 ; 4.730 ; 44.407$

1 Neuf sondages ont été réalisés sur les parcelles ZD 436 et 225, rue des Frères Montgolfier au préalable à la construction d'un lotissement de 12 lots. Les sondages 7,8 et 9 ont permis la découverte d'une occupation antique localisée au sud du projet d'aménagement. Elle s'installe dans un secteur où les graviers de la terrasse du Rhône sont hauts, et où les niveaux argileux gris témoignant sans doute de la présence d'un secteur plus humide observé dans les sondages 4,5 et 6 ont disparu. Cette occupation se caractérise par un bâtiment, orienté nord-sud, constitué de murs dont le mode de construction est variable (murs de galets maçonnés ou non, murs de fragments de tuiles) avec des sols de terre battue. Cette variété dans le mode de construction peut aller dans le sens d'une occupation constituée de plusieurs états successifs. L'amplitude stratigraphique de cette installation rurale reste limitée : environ $0,30 \mathrm{~m}$ contenant les niveaux de démolition, les sols et les maçonneries (US 7-5, 8-5 et 9-4). Toutefois, on ne peut exclure la présence de structures légères (fosse et/ou trous de poteau) comme en témoignent quelques anomalies relevées dans les graviers de la terrasse dans le sondage 9 et dont la fonction n'a pu être interprétée. Seule une observation fine avec un nettoyage manuel peut permettre d'identifier les murs composés des mêmes éléments que les niveaux de démolition et les sols sommaires de terre battue. Le mobilier retrouvé dans les niveaux associés à ce bâtiment permet de proposer une datation de cette installation au III e s. apr. J.-C. 
INDEX

Index chronologique : Antiquité

Index géographique : Rhône-Alpes, Drôme (26), Pierrelatte

Keywords : Antiquity

operation Opération préventive de diagnostic (OPD), 2013 - n OA : 2211172

Mots-clés : bâtiment

AUTEURS

CHRISTINE RONCO

Inrap 